\title{
75 éve nyílt meg \\ a Magyar Királyi Horthy Miklós Tudományegyetem Szegeden
}

\author{
Hencz Péter dr.
}

Az 1940. augusztus 30-i II. bécsi döntés értelmében Észak-Erdélyt és Székelyföldet visszacsatolták az anyaországhoz. Az 1940. XXVIII. tc. alapján az ideiglenesen Szegeden múködő Ferenc József Tudományegyetem visszatérhetett ősi székhelyére, szülőhelyére, Kolozsvárra.

Szegeden a kolozsvári egyetem hazatértével jogi értelemben új egyetem jött létre. Ezzel Szeged másfél évszázados álma teljesült: saját egyeteme lett. Az egyetem valójában a kolozsvári egyetem szellemi és tudományos örökségét vitte tovább. Az egyetem és a professzorok nagyobb része Szegeden maradt. Így a kolozsvári fóág, amely Szegeden már gyökeret vert, itt maradt, a mellékhajtás virágzott ki újból szülőhelyén. A szegedi egyetemet a kormányzóról nevezték el: Magyar Királyi Horthy Miklós Tudományegyetem lett. Az egyetem első rektorává a kormányzó a Nobel-díjat elnyert Szent-Györgyi Albertet nevezte ki [1].

A megnyitóra országos ünnepség keretében 1940. november 11 -én került sor. A város ünnepi díszbe öltözött, a házakat fellobogózták, az utcákon ünneplő tömegek sorakoztak. Ünnepi misére hívtak a harangok a Fogadalmi templomba, amelyet Glattfelder Gyula megyés fópásztor pontifikált. „Én vagyok az út, az igazság és az élet" - mondta homíliájában, idézve a Bibliát.

Az ünnepségre a központi egyetem aulájában került sor. Jelen volt többek közt Horthy Miklós kormányzó, akit óriási ováció köszöntött, Teleki Pál miniszterelnök, Szeged országgyúlési képviselője, Serédi Jusztinián bíboros-hercegprímás, Hóman Bálint vallás- és közoktatásügyi miniszter, társegyetemek képviselői, Klebelsberg Kunó özvegye, valamint az egyetemi tanács tagjai, élükön Szent-Györgyi Albert rektorral [2].

A Himnusz eléneklése után Hóman Bálint nyitotta meg az egyetem első ülését. Fontosabb gondolatai a következők voltak:

Beszéde kezdetén megemlékezett nagy elődjéről, Klebelsberg Kunó grófról, „... akinek szívében fogant pompás egyetemi városban új életre kel szívének legkedvesebb gyermeke: a szegedi egyetem". Dicsérte a városi vezetők bölcsességét és polgárainak áldozatosságát, amelynek eredményeképpen az egyetem Magyarország egyik legkiemelkedőbb kulturális központja, a tudományosság erős vára lett. Kérte, hogy a tanárok járjanak elől a múveltséggyarapító munkában. Hallgatói, köztük a magyar Alföld földmúves népének tehetséges fiai, komoly hivatástudattal tanuljanak, hozzanak új erôt, vidám vállalkozó kedvet és komoly alkotókészséget a magyar értelmiségbe.

Az igazság keresése az egyik legnagyobb érték a tudományban. A tudós által termelt szellemi javak az egyetemes tudomány részeivé válnak, az egész emberiséget szolgálják. A tudomány ebben az értelemben nemzetközi, nemzetek feletti, határokat átívelő. De ez korántsem jelenti a nemzet életétól való elszakadást, avagy a nemzetellenességet. Minden nép tudományának alkotásai magukon viselik a nemzeti sajátosságot.

Az egyetemi tanár hármas hivatást tölt be: tudós, tanítómester és nemzetnevelő. Tudományosságával gazdagítja nemzetének szellemi javait. Mint tanító vezetőket képez a társadalom részére. Erkölcsi nevelésével előmozdítja az egészséges közszellemet.

Az egyetem a kedvezmények adásánál egyedül a ráutaltságot, a szorgalmat és tanulmányi eredményeket veszi figyelembe. Nem kaphatnak előnyt a vagyonosok gyermekei, sem pedig a bukdácsoló diákok. „Magyarországon minden szorgalmas és tehetséges magyar ifjúnak - származzék bármelyik társadalmi rétegből - joga van a tanulásra. ... Pusztán szánalomból, elnézésből, szeretetből nem segíthetünk senkit diplomához, mert a hiányos képzettségü, lelkiismeretlen orvosokkal, tanárokkal, képzetlen mérnökökkel mérhetetlen károkat okozunk nemzetünknek. Mindent el fogunk követni, hogy minden tanulni vágyó szegény és szorgalmas diák diplomához jusson.”

Ezt követően a kormányzó, Horthy Miklós szólt az ünneplőkhöz:

Erre az egyetemre nagy feladat hárul a magyar jövő megalapozásával. „Nemzetünk jövendo” sorsa azon is fordul, hogy milyen lesz múveltsége. Ha meg akarunk állni a népek nagy versenyében, sok tudósra és alapos ismeretekre, derék, munkás, jellemes, múvelt magyar ifjak ezreire van szükségünk. ... A szegedi egyetemnek különös gondot kell fordítania a természettudományok korszerű múvelésére, eredményeinek ismertetésére, különösen a régebben annyira elhanyagolt Alföld népében rejlő őserőinek felkutatására és kimúvelésére" [3]. 
„Amidőn ezt az új egyetemet rendeltetésének átadom, bizonyos vagyok benne, hogy méltó hajléka lesz az ezeréves magyar kultúrának. Ebben a meggyőződésben kérem az egész jövő múködésére a Mindenható áldását.”

Ezt követően került sor Szent-Györgyi Albert székfoglaló beszédére. Bevezetőjében dicsérte a kormányzó érdemeit: „... aki Szegedről megindulva bátorságával, bölcsességével, önfeláldozásával és lángoló hazaszeretetével ezt az országot elesettségéből felemelte és megcsonkítottságában kiegészítette."

„Jogilag új egyetem vagyunk, de a mi gyökereink is messze nyúlnak vissza, és semmiféle jogi formula nem fejezi ki azt a bensőséges viszonyt, ami minket a kolozsvári Ferenc József Tudományegyetemhez köt. Mi egy törzsnek vagyunk a két hajtása..."

Méltatta gróf Klebelsberg Kunó érdemeit, „... aki tíz esztendőn keresztül viselte széles vállán ennek a kettős hajtásnak közös törzsét, a szegedi Ferenc József Tudományegyetemet”.

Dicsérte Szeged lakosságát, amely szegénysége idején a legnagyobb áldozattól sem riadt vissza.

Beszélt az egyetem hármas feladatáról: „Legősibb hivatása, gyújteni, terjeszteni és gyarapítani az emberi tudást. Második feladata, kisszámban nevelni a jövőnek tudósokat, akik majdan ezt a hivatást tólünk átveszik. Újabb eredetú, de nem kevésbé magasztos az egyetemnek harmadik hivatása, nevelni a haza részére polgárokat, kik el vannak látva a szellem fegyverével. ... A mi egyetemünknek van még egy negyedik, különleges hivatása is: hogy a nagy magyar Alföldnek szellemi központja legyen.”

Az egyetem egyik legfőbb feladata és kötelessége a kutatás, új igazságok keresése. Falai között meg kell őriznie a teljes szellemi szabadság levegőjét, amely nélkül minden kultúra elsorvad. „Jó tanítás csak ott folyhat, ahol él a kutatás szelleme, az igazságok lelkes, pártatlan szeretete. De a tudományos kutatómunkánkkal hazafias kötelességünket is teljesítjük, mert hiszen éppen a tudomány, a kultúra az egyetlen terep, amelyen a versenyt a nagy nemzetekkel egy kis nemzet is felveheti."

„Az egyetemnek felül kell emelkednie a politika hullámzásán. Kapuin csak úgy léphetünk be, hogy a gyúlölködést kizárjuk és a tudás szelíd fénye mellett munkálkodunk. ... Az egyetem korábban tudósokat nevelt, de a hallgatók többsége nem tudós akar lenni. Ezért az egyetemnek egyrészt előadásaikkal a közéletre kell felkészíteni, másrészt diákjait a tudomány legmagasabb múvelésére kell megtanítania. Oktatásunk legnagyobb hibája, hogy a tanítást inkább a tananyag, mint a hallgató szemszögéből ítéli meg."

Tanítson vagy neveljen-e az egyetem? - szintén alapvető kérdés. Ha az egyetem egyik hivatása a hasznos köz- életi tevékenységre való felkészítés, elég, ha a tudás átadására törekszik. „De, ha tőlük nemcsak a szaktudást, de a jellem és szellembeli tulajdonságok egész sorát is kívánjuk, mint a hivatottság érzését, az alkotás és cselekvés vágyát, a felelősség érzését, a tettrekészséget, a józan és gyors ítéletet, a becsületességet, az érdeklődést, az önzetlenséget, mely tulajdonságok nélkül a szaktudás csak fél embert jelent, akkor nyilván nevelnünk is kell." A hivatás betöltéséhez még egészség is kell, amiről szintén az egyetemnek kell gondoskodnia.

„Az érdeklődés, a tudásvágy, az önálló gondolkodás fejlesztése fontosabb, mint az adatoknak a fejbe préselése, mert hetekkel a vizsga után üres fejjel és kézzel adjuk át őket az életnek."

Az egyetem egyik nehézsége, hogy a középiskola száraz, túltömött anyagával nem hangsúlyozza eléggé a jellem és szellem kifejlesztését. „Egy színjeles érettségi bizonyítvány nekünk nem ad felvilágosítást arról, hogy az illető egy kiválóság, avagy egy értéktelen magoló. Kívánatos lenne, hogy padjainkba csakis azok kerüljenek, akikben megvan az adottság a szellemi pályára, tekintet nélkül a szülők anyagi vagy társadalmi helyzetére."

Másik nehézségünk egyetemeink túlzsúfoltsága, a hallgatóság és a tanszemélyzet aránytalansága. „Pedig nevelői és tanítói hivatásunkat csak úgy teljesíthetjük igazán, ha a tanár tanítványának nemcsak cenzora, de barátja, munkatársa és idősebb testvére.” Ehhez a felelősségteljes munkához kérte Isten segedelmét, adjon erôt és békét hazánknak [2, 3].

Az üdvözléseket a társegyetemek és az egyetemi ifjúság képviselőjének köszöntése zárta.

A fennkölt ünnepség a Szózat eléneklésével fejeződött be.

\section{Irodalom}

[1] Makk, F., Marjanusz, L. (eds.): The History of the University of Szeged (1581-2011). [A Szegedi Tudományegyetem és elődei története (1581-2011).] Szegedi Egyetemi Kiadó, Szeged, 2011. [Hungarian]

[2] Horthy Miklos University opened by the address of our Regent in magnificant, nationwide ceremony. [Kormányzó urunk beszédével, országra szóló fényes ünnepség keretében nyílt meg a Horthy Miklós-egyetem.] Délmagyarország, 1940. november 12., 1-3. [Hungarian]

[3] Ceremonial start of the university. In: Szent-Györgyi, A. (ed.): Report on the Activity of the Hungarian Royal Horthy Miklos University in Szeged in the 1940/41 Acedemic Year. [Az egyetem ünnepélyes megnyitása. In: Szent-Györgyi, A. (szerk.): Beszámoló a Szegedi Magyar Királyi Horthy Miklós Tudományegyetem 1940-41. tanévi múködéséról.] A M. Kir. Horthy Miklós Tudományegyetem kiadása, Szeged, 1943. [Hungarian] 